\title{
A LEI DE BIOSSEGURANÇA SOB A ABORDAGEM DA ÉTICA DISCURSIVA*
}

\section{THE LAW OF BIOSECURITY UNDER THE BOARDING OF THE DISCOURSE ETHICS}

\author{
Valkíria Aparecida Lopes Ferraro* \\ Simone Vinhas de Oliveira
}

\begin{abstract}
Resumo: A atividade biotecnologia indica uma perspectiva de modificação social e de ecossistemas com uma imprevisão sobre os resultados dessas alterações. Isso toca em questões ético-jurídicas, pois, denota riscos para as sociedades contemporâneas. A criação de espaços públicos de participação popular significa uma proposta procedimental de controle dos possíveis abusos da atividade biotecnológica e a pretensa coibição das temeridades. Nesse sentido, a ética discursiva representa uma peça chave de um projeto de radicalização democrática pelo qual são válidas e aceitas normas que exprimem uma vontade universal no desenvolvimento biotecnológico - Princípio Universal. E essa vontade, como uma vontade racional definida pela intersubjetividade da racionalidade comunicativa, só seguirá uma norma se ela for universal na medida em que todos os setores interessados no desenvolvimento biotecnológico participarem dos discursos - Princípio do Discurso. Para Habermas, as normas fundamentadas discursivamente fazem valer ao mesmo tempo duas coisas: o conhecimento daquilo que a cada momento reside no interesse de todos, bem como uma vontade geral que apreendeu em si mesma, sem repreensão, a vontade de todos. Diante desses fundamentos, tecem-se reflexões sobre um dos efeitos da Lei de Biossegurança - a criação de um poder discricionário da CTNBio e a ausência de regulamentação do CNBS. Tais fatos são assimétricos para o atual modelo democrático, bem como impossibilita um processo de radicalização democrática.
\end{abstract}

Palavras-chave: Biotecnológica. Democracia. Ação comunicativa. Ética discursiva. Biossegurança.

Artigo produzido como resultado de pesquisas em andamento no projeto de pesquisa cadastrado pela Universidade Estadual de Londrina sob o nª 04511 - Biotecnologia e Direito: A Possibilidade Jurídica da Utilização de Células Embrionárias em Período de Descarte sob o Prisma da Lei de Biossegurança, de autoria da segunda sob a coordenação da primeira.

* Doutora em Direito Civil pela PUC/ São Paulo. Professora permanente do Programa de Mestrado em Direito Negocial da Universidade Estadual de Londrina.

**** Mestranda do Programa de Mestrado em Direito Negocial da Universidade Estadual de Londrina. 
Valkíria Aparecida Lopes Ferraro; Simone Vinhas de Oliveira

\begin{abstract}
The biotechnology activity indicates a perspective to social and ecosystems modifications with improvidence about the results of these alterations. This involves ethical-legal topics, therefore, denotes risks for the contemporary society. The creation of public spaces with popular participation means a procedural proposal of control the possible imposes of the biotechnological activity and intend suppress the temerity. In this way, the discoursive ethics represent a key part of a project of democratic radicalization for which they are valid and accepted norms as universal state, this will in the biotechnological development - Universal Principle. And this will, as a rational will defined by the intersubjectiv of the communicative rationality, will only follow a norm if it will be universal in the measure and all the sectors interested in the biotechnological development to participate of the speeches - Principle of the Speech. For Habermas, the grounded discoursive norms make to be valid for two topics: the knowledge of something that exist in each moment and the every one interest, and also the general will that learned, without pressure, the will of everyone. With all those fundaments, it is able to have thoughts about the effect of the Biosecurity Law - the creation of one discretionary power to regulate the biotechnology activities thought CTNBio and the absence of regulation of the CNBS. These facts are asymmetric for the actual democratic stander and make unable the process of democratic radicalization.
\end{abstract}

Keywords: Biotechnological. Democracy. Communicative action. Discoursive ethics. Biosecurity.

\title{
1 INTRODUÇÃO
}

Por uma análise empírica sobre a produção legislativa que regulam a atividade biotecnológica, realizou-se um recorte sobre a Lei de Biossegurança, verificandose um dos seus o efeito imediato: o poder discricionário da Comissão Técnica Nacional de Biossegurança (CTNBio).

Esse modelo de normatização é assimétrico aos fundamentos éticos democrático, pois, trata-se de um órgão tecnocrata, vinculado ao poder executivo, decidindo, exclusivamente, sob a regulação da atividade biotecnológica.

Esse poder discricionário da CTNBio adverte para uma ausência de representatividade popular na regulação da CTNBio e aponta para uma ilegitimidade desta forma de normatização.

A discricionalidade do CTNBio, além de não legitimada no modelo democrático atual, nos distancia, ainda mais, do ideal de radicalização democrática conciliando a autonomia privada com o exercício da autonomia pública pelos fundamentos da ética discursiva, que converge à ampla participação popular. 
A Lei de Biossegurança sob a abordagem da ética discursiva

A procedimentalização dessa participação pode ocorrer por meio da regulamentação do Conselho Nacional de Biossegurança (CNBS) como forma de controle dos abusos possíveis cometidos pela biotecnologia.

\section{A RACIONALIDADE DA BIOTECNOLOGIA E OS PRINCÍPIOS DA ÉTICA DISCURSIVA}

$\mathrm{Na}$ segunda metade do XIX, o processo de desenvolvimento biotecnológico genético iniciou-se com o monge Gregor Mendel que, estudando as ervilhas do mosteiro, formulou leis estatísticas da hereditariedade. A partir disso, a investigação genética cresceu rapidamente pelo aperfeiçoamento dos instrumentos em laboratório com maior precisão nos exames microscópios das células, permitiramse desvelar suas estruturas e as informações genéticas presentes. Desde então, a biotecnologia progrediu revelando os segredos do DNA, revelando o código genético, transferindo e manipulando genes.

Na práxis tecno-científica, em especial na biologia molecular, com o domínio técnico sobre as estruturas, formas e conteúdos da vida nas espécies, há uma racionalidade tecno-instrumental da Modernidade ${ }^{1}$. Nesse sentido, Habermas (1986) coloca que no universo da tecnologia há uma grande racionalização da ausência de liberdade do homem que demonstra a impossibilidade da autonomia, da capacidade de decisão sobre a própria vida. Isto significa que a racionalidade da ciência e da técnica é, por essência, uma racionalidade de dispor, uma racionalidade de dominação.

${ }^{1}$ A Modernidade proporcionou uma transição do modelo de racionalidade baseado na tradição da religião e nos costumes para a racionalidade fundamentada na autonomia da razão (cientificismo). Na obra O Discurso Filosófico da Modernidade, Habermas explica que filosoficamente a primeira auto-avaliação sistemática da modernidade que foi feita por Kant, Marx e Hegel, mas que só teve eco no início do século XX, quando foi radicalizada por Max Weber e pela Escola de Frankfurt. Acrescentam, ainda, as contribuições de pensadores como Nietzsche, Heidegger e Foucault, cujas interpretações têm gerado sérios desdobramentos com relação ao próprio significado da Modernidade, os quais levaram a uma concepções que identifica a Modernidade como um modelo de racionalidade que só levou à miséria e dominação de um ser humano instrumentalizado em critérios técnico-científicos. Esses últimos são precursores do movimento denominado pós-modernismo.

Apesar de considerar relevantes as contribuições dos autores pós-modernos como um diagnóstico pertinente às estruturas de dominação da modernidade, Habermas, ao contrário destes, retoma o projeto da modernidade e acrescenta uma construção teórica baseada numa racionalidade comunicativa como proposta ética para interferir na racionalidade instrumental de dominação. 
Valkíria Aparecida Lopes Ferraro; Simone Vinhas de Oliveira

A racionalidade instrumental da biotecnologia obedece aos critérios da competitividade e dominação, cujos fins estão em si próprios e não na coletividade. Isso significa que o agir está voltado aos resultados das pesquisas, tendo como fim o avanço do domínio da técnica exclusivamente, o qual o próprio homem passou a ser objeto e perdeu a condição de sujeito.

Essa racionalidade instrumental (individualista e competitiva) provoca os riscos para sociedade na medida em que proporciona um desequilíbrio entre os que dominam a biotécnica e os que não dominam e debelam os maiores impactos na sociedade, o qual o conteúdo das descobertas interfere profundamente nas forças da natureza como nenhuma outra tecnologia antes conhecida. Nesse contexto, quanto mais poderosas são as novas tecnologias, maiores são as possibilidades de destruição dos ecossistemas e de modificação social, o que envolve o interesse geral da sociedade, interferindo, assim, na liberdade, na autonomia ${ }^{2}$ e na dignidade ${ }^{3}$ humana.

Nesse contexto, a teoria do agir comunicativo de Habermas apresenta a ética do discurso $\mathrm{S}^{4}$, cujo elemento fundamental para orientar a conduta biotecnológica é à existência de princípios e como esses princípios devem ser entendidos por

${ }^{2} \mathrm{O}$ conceito de autonomia está inseparavelmente relacionado à idéia de liberdade. A autonomia é definida no contexto de liberdade em oposição à heteronomia. A autonomia do sujeito se expressa na sua capacidade de autodeterminação, na sua vontade legisladora de estabelecer e concretizar fins no mundo social. Esses fins só podem ser alcançados através de certos meios. Isto significa que toda legislação decorrente da vontade legisladora dos homens precisa ter como finalidade o próprio homem, a espécie humana como tal. Mais especificamente a vida e a dignidade do homem. O imperativo Categórico orienta-se, pois, segundo um valor básico, inquestionável e universal: a dignidade da vida humana (FREITAG, 1989, p. 10).

${ }^{3}$ Kant admite que no mundo social, nos sistemas de fins, existem duas categorias de valores: o preço e a dignidade. Enquanto o preço representa um valor exterior e a manifestação de interesses particulares, a dignidade representa um valor interior, interesse geral. A legislação elaborada pela razão prática deve levar em conta, como finalidade suprema, a realização desse valor interior e universal: dignidade humana. (FREITAG, 1989, p. 10).

${ }^{4}$ A ética discursiva de Habermas pressupõe pelo menos três dados, ainda não suficientemente explicitados: a competência comunicativa dos integrantes do grupo; situações dialógicas ideais, livres de coerção e violência; e, finalmente, um sistema lingüístico elaborado que permita pôr em prática o discurso (teórico e prático). Quando a ação instrumental e a comunicativa não conseguem (pacificamente) resolver tais problemas, Habermas admite a ação estratégica (instrumental), cuja função primordial consistiria em estabelecer as condições materiais e políticas para que a ação comunicativa e, no contexto dela, o discurso prático possam entrar em ação. (FREITAG, 1989, p. 38). 
A Lei de Biossegurança sob a abordagem da ética discursiva

uma racionalidade comunicativa ${ }^{5}$ por meio de um ato ideal e situações de falas ideais. $\mathrm{O}$ ato de fala ideal apresenta uma racionalidade comunicativa em seus argumentos e a situação ideal de fala significa a participação de todos os setores interessados com atos de fala ideal nos discursos do qual se constrói o consenso pela a força do melhor argumento ${ }^{6}$.

Habermas desenvolve a Ética Discursiva para a política, a ética e o Direito, o qual considera válidas as normas de ação às quais todos os possíveis atingidos poderiam dar o seu assentimento, na qualidade de participantes de discursos racionais. (HABERMAS, 2001, p. 142).

Nas palavras de Freitag (1989) a ética discursiva de Habermas é uma das peças-chaves do projeto de radicalização democrática. A questão da moralidade confunde aqui com a questão da democracia: debate público.

A partir desse paradigma procedimental ético pode-se construir uma análise empírica sobre a produção normativa ${ }^{7}$ que regulam a atividade biotecnológica.

${ }^{5} \mathrm{O}$ agir comunicativo comporta uma racionalidade baseada nos princípios de justiça e solidariedade, que busca seus os fins nos entendimento com a definição do interesse geral que pode interagir com outros sistemas no mundo da vida cuja racionalidade é instrumental, em especial com o sistema tecno-ciência que busca os fins em si mesmo. (DUTRA, 2005, p. 57.)

${ }^{6}$ Em sua essência, a ética discursiva procura substituir o imperativo categórico de Kant pelo procedimento da argumentação moral. Dessa forma, o imperativo categórico é transformado em um princípio universalizável, na situação dialógica ideal, perdendo sua autoridade como critério moral absoluto "puro". A ética discursiva sugere que somente podem aspirar à validade aquelas normas que tiverem o consentimento e a aceitação de todos os integrantes do discurso prático. Para que uma norma tenha condições de transformar-se em norma geral, aspirando validade universal enquanto máxima da conduta de todos os participantes do discurso prático, os resultados e efeitos colaterais decorrentes da sua observância precisam ser antecipados, pesados em suas conseqüências e aceitos por todos. Isto ocorre através de um procedimento argumentativo em que prevalece o melhor argumento, respeitados todos os demais, à luz de sua maior coerência, justeza e adequação. O caráter universal de uma norma ou princípio moral qualquer só se evidencia se tal princípio ou norma não exprimir meramente a intuição moral de uma cultura ou época específica, mas sim um conteúdo que possa ter validade geral, fugindo a toda e qualquer forma de etnocentrismo. (FREITAG, 1989, p. 36).

${ }^{7}$ Em 24 de março de 2005, o Presidente da República, Luiz Inácio Lula da Silva sancionou a Lei da Biossegurança $\mathrm{n}^{\mathrm{a}}$. 11.105 / 2005. A lei de biossegurança representa o principal instrumento regulatório da atividade científica na área da biotecnologia. 
Valkíria Aparecida Lopes Ferraro; Simone Vinhas de Oliveira

\section{A LEI DE BIOSSEGURANÇA SOB A ABORDAGEM DA ÉTICA DISCURSIVA}

A Lei da Biossegurança n⿳a . 11.105/2005 foi elaborada com um dos propósitos de regulamentar o Artigo 225, §1 $\underline{a}$, incisos II, IV e V da Constituição Federal, reunindo quatro relevantes matérias diversas: a pesquisa e a fiscalização dos organismos geneticamente modificados (OGM); a utilização de células-tronco embrionárias para fins de pesquisa e terapia; o papel, a estrutura, as competências e o poder da CTNBio; e, por fim, a formação do Conselho Nacional de Biossegurança (CNBS).

Trata-se de um conteúdo amplo e diverso no corpo de uma mesma lei o que adverte para uma superficialidade das discussões realizadas. É evidente, então, que não houve a possibilidade de participação de todos os setores sociais, considerando o breve tempo e a ausência espaço público para debate combinado com uma diversidade de temas desta lei.

A Lei de Biossegurança partiu da regulamentação dos transgênicos, em especial o plantio de semente transgênica, para se alcançar a regulamentação de técnicas de reprodução humana assistida. O resultado dessa regulamentação ocorreu conforme tanto os interesses de laboratórios e de centros de pesquisas com células humanas como também para do agronegócio. Isto é, a Lei de Biossegurança foi elaborada com um caráter fragmentário e instrumental de setores da sociedade que tinham interessem próprios e individuais entre os diversos temas tratados.

A racionalidade instrumental é inerente aos sistemas econômico e tecnocientífico, os quais pertencem o agronegócio, centros de pesquisas e laboratórios. Esse agir instrumental resulta em benefício para a sociedade como o desenvolvimento econômico e o avanço científico. Entretanto, a racionalidade instrumental não realiza discursos que consideram os efeitos nocivos e irreversíveis para toda humanidade entre os temas da biotecnologia, pois seu fim está em si mesmo e não na coletividade e por isso a racionalidade instrumental não pode construir uma racionalidade comunicativa.

A racionalidade comunicativa pode interagir com o agir instrumental destes sistemas pelo tratamento ético. Ou seja, a ética discursiva pode conduzir formalmente a validez das normas do paradigma procedimental. Dessa maneira, a Ética do Discurso conduz como a sociedade entende o princípio da precaução, por exemplo, para atividade biotecnologia pela força do melhor argumento ${ }^{8}$.

Trata-se da reconstrução do imperativo categórico ${ }^{9}$ pela linguagem. A

${ }^{8}$ Explica McCarthy (1998), a chave da noção habermasiana da obtenção de um acordo é a possibilidade de fazer uso de razões com que possa chegar a um reconhecimento intersubjetivo de pretensões de validade suscetíveis de crítica. Assim, a prática comunicativa possibilita aos participantes entrarem num processo argumentativo, no 
A Lei de Biossegurança sob a abordagem da ética discursiva

universalização do princípio é um processo dialógico. No princípio estão presentes os aspectos cognitivo e prático do agir comunicativo dos sujeitos por meio da linguagem. Em Kant, a objetividade do imperativo categórico tem um aspecto monológico e abstrato no sujeito apriórico. E pode ser reconstruído racionalmente numa perspectiva universalista. (BOUFLEUER, 2001). Habermas se fundamenta na intersubjetividade e no dialogo, pois entende a objetividade do como devo agir da norma baseado na racionalidade consensual comunicativa. Pelos aspectos formais da intersubjetividade, a teoria habermasiana é processual, dialógica e comunicativa envolvendo a participação dos sujeitos nos discursos.

Pelo Princípio da Universalização, a ética discursiva só considera válidas normas que exprimem uma vontade universal. Isto é, uma razão comunicativa que incluem as situações ideais oferecidas pelo conhecimento do interesse geral. E com o Princípio do Discurso, elaboram-se as situações ideais de fala como método para alcançar um consenso. As situações ideais incluem os interlocutores necessários nos discursos, ou seja, a expressão da vontade universal depende da garantia de participação de todos os setores da sociedade na discussão para elaboração da norma. Não há um conteúdo, mas, uma forma (Princípio da Universalização e Princípio do Discurso) como Princípio Ético que representam a procedimentalização do entender os princípios presente nas normas.

$\mathrm{Na}$ Lei de Biossegurança ressalta uma ausência de critérios para a atividade biotecnológica devido à mistura de temas ${ }^{10}$ combinado com o poder ${ }^{11}$ discricionário da CTNBio.

Com isso, o efeito imediato da Lei de Biossegurança foi constituir como

qual permanece sempre aberta a possibilidade de identificar e corrigir os erros, ou seja, de aprender com eles.

9 "O imperativo categórico declara a ação como objetivamente necessária por si, independentemente de qualquer intenção, quer, sem quaisquer outras finalidades, vale como princípio apodíco (prático).” (KANT, 1980, p. 125).

${ }^{10}$ Lei da Biossegurança nª 11.105 / 2005, Artigo 1aㅡ Esta Lei estabelece normas de segurança e mecanismos de fiscalização sobre a construção, o cultivo, a produção, a manipulação, o transporte, a transferência, a importação, a exportação, o armazenamento, a pesquisa, a comercialização, o consumo, a liberação no meio ambiente e o descarte de organismos geneticamente modificados - OGM e seus derivados, tendo como diretrizes o estímulo ao avanço científico na área de biossegurança e biotecnologia, a proteção à vida e à saúde humana, animal e vegetal, e a observância do princípio da precaução para a proteção do meio ambiente.

${ }^{11}$ Lei da Biossegurança $n^{\mathrm{a}}$. 11.105 / 2005, Artigo. 14 Compete à CTNBio: I - estabelecer normas para as pesquisas com OGM e derivados de OGM; 
Valkíria Aparecida Lopes Ferraro; Simone Vinhas de Oliveira

órgão regulador dos critérios de segurança a Comissão Técnica Nacional de Biossegurança (CTNBio). Resta examinar a legitimidade das decisões dos membros desta Comissão pelos fundamentos democráticos.

\section{O PODER DISCRICIONÁRIO DA CTNBio NOS LIMITES DO ESTADO DEMOCRÁTICO DE DIREITO}

No contexto atual, a principal regulação da atividade biotecnológica, no país, ocorre por meio da CTNBio ${ }^{12}$, vinculada ao ministério de Ciência e Tecnologia.

Ante a ausência de critério da Lei de Biossegurança diante da variabilidade de

II - estabelecer normas relativamente às atividades e aos projetos relacionados à

OGM e seus derivados;

III - estabelecer, no âmbito de suas competências, critérios de avaliação e monitoramento de risco de OGM e seus derivados;

IV - proceder à análise da avaliação de risco, caso a caso, relativamente a atividades e projetos que envolvam OGM e seus derivados;

V - estabelecer os mecanismos de funcionamento das Comissões Internas de Biossegurança - CIBio, no âmbito de cada instituição que se dedique ao ensino, à pesquisa científica, ao desenvolvimento tecnológico e à produção industrial que envolva OGM ou seus derivados;

VI - estabelecer requisitos relativos à biossegurança para autorização de funcionamento de laboratório, instituição ou empresa que desenvolverá atividades relacionadas à OGM e seus derivados;

VII - relacionar-se com instituições voltadas para a biossegurança de OGM e seus derivados, em âmbito nacional e internacional;

VIII - autorizar, cadastrar e acompanhar as atividades de pesquisa com OGM ou derivado de OGM, nos termos da legislação em vigor;

IX - autorizar a importação de OGM e seus derivados para atividade de pesquisa;

$\mathrm{X}$ - prestar apoio técnico consultivo e de assessoramento ao CNBS na formulação da PNB de OGM e seus derivados;

XI - emitir Certificado de Qualidade em Biossegurança - CQB para o desenvolvimento de atividades com OGM e seus derivados em laboratório, instituição ou empresa e enviar cópia do processo aos órgãos de registro e fiscalização referidos no art. 16 desta Lei;

XII - emitir decisão técnica, caso a caso, sobre a biossegurança de OGM e seus derivados no âmbito das atividades de pesquisa e de uso comercial de OGM e seus derivados, inclusive a classificação quanto ao grau de risco e nível de biossegurança exigido, bem como medidas de segurança exigidas e restrições ao uso;

XIII - definir o nível de biossegurança a ser aplicado ao OGM e seus usos, e os respectivos procedimentos e medidas de segurança quanto ao seu uso, conforme as normas estabelecidas na regulamentação desta Lei, bem como quanto aos seus derivados; 
A Lei de Biossegurança sob a abordagem da ética discursiva

temas, a CTNBio normativa a atividade biotecnológica estabelecendo critério para autorizar ou não determinada atividade. Em que pese haver uma necessidade de órgão de apoio técnico para o poder executivo com essa comissão, a sua competência de regular plenamente a atividade biotecnológica por meio de autorização e certificação é assimétrica aos fundamentos éticos tanto para modelo de democracia de representação popular e também para o modelo ${ }^{13}$ de democracia de participação.

Essa forma de regulação encerra uma discrepância com o modelo Democrático

XIV - classificar os OGM segundo a classe de risco, observados os critérios estabelecidos no regulamento desta Lei;

XV - acompanhar o desenvolvimento e o progresso técnico-científico na biossegurança de OGM e seus derivados;

XVI - emitir resoluções, de natureza normativa, sobre as matérias de sua competência; XVII - apoiar tecnicamente os órgãos competentes no processo de prevenção e investigação de acidentes e de enfermidades, verificados no curso dos projetos e das atividades com técnicas de ADN/ARN recombinante;

XVIII - apoiar tecnicamente os órgãos e entidades de registro e fiscalização, referidos no art. 16 desta Lei, no exercício de suas atividades relacionadas à OGM e seus derivados; XIX - divulgar no Diário Oficial da União, previamente à análise, os extratos dos pleitos e, posteriormente, dos pareceres dos processos que lhe forem submetidos, bem como dar ampla publicidade no Sistema de Informações em Biossegurança SIB a sua agenda, processos em trâmite, relatórios anuais, atas das reuniões e demais informações sobre suas atividades, excluídas as informações sigilosas, de interesse comercial, apontadas pelo proponente e assim consideradas pela CTNBio;

XX - identificar atividades e produtos decorrentes do uso de OGM e seus derivados potencialmente causadores de degradação do meio ambiente ou que possam causar riscos à saúde humana;

XXI - reavaliar suas decisões técnicas por solicitação de seus membros ou por recurso dos órgãos e entidades de registro e fiscalização, fundamentado em fatos ou conhecimentos científicos novos, que sejam relevantes quanto à biossegurança do OGM ou derivado, na forma desta Lei e seu regulamento;

XXII - propor a realização de pesquisas e estudos científicos no campo da biossegurança de OGM e seus derivados;

XXIII - apresentar proposta de regimento interno ao Ministro da Ciência e Tecnologia. $\S 1^{\mathbf{a}}$ Quanto aos aspectos de biossegurança do OGM e seus derivados, a decisão técnica da CTNBio vincula os demais órgãos e entidades da administração.

$\S 2^{\mathbf{a}}$ Nos casos de uso comercial, dentre outros aspectos técnicos de sua análise, os órgãos de registro e fiscalização, no exercício de suas atribuições em caso de solicitação pela CTNBio, observarão, quanto aos aspectos de biossegurança do OGM e seus derivados, a decisão técnica da CTNBio. 
Valkíria Aparecida Lopes Ferraro; Simone Vinhas de Oliveira

representativo porque não há representação popular nessa espécie de atividade normativa. O poder legislativo é o poder legitimado para elaborar normas de relevância social pela sua representatividade popular. Os possíveis impactos e a imprevisibilidade gerados pela biotecnologia constituem a relevância social das normas sobre esse tema. A ausência de critério na Lei de Biossegurança, ou seja, suas omissões não legitimam um outro poder (executivo), a não ser o próprio legislativo saná-las. Por serem essas normas de relevância social, devem ser produzidas pelo poder legislativo para serem legítimas conforme os fundamentos democráticos de representação.

Torna-se, assim, evidente a assimetria do poder discricionário da CTNBio tanto com o modelo democrático atual, bem como com os fundamentos éticos que buscam uma ampla participação popular nas decisões políticas do Estado: radicalização da Democracia.

Para Hans Jonas, o novo imperativo está endereçado muito mais à política pública que à conduta privada diante do paradoxo da tecnologia, que exerce poder e foge do controle, requer-se algum tipo de "poder sobre o poder". Há

${ }^{12}$ Conforme o Artigo $1^{\underline{a}}$ e seus parágrafos, os agentes deverão, obrigatoriamente, requerer a autorização do Conselho Nacional de Biossegurança - CTNBio que deverá fornecer Certificado de Qualidade em Biossegurança sob pena de estabelece a coresponsabilidade dos agentes nas atividades e pesquisa quanto aos seus efeitos em decorrência do descumprimento. O art. 14 reafirma a competência do CTNBio em estabelecer parâmetros e requisitos de segurança, ou seja, aprovar ou não as atividades ou pesquisas com OGM.

${ }^{13} \mathrm{O}$ modelo elaborado para legitimar ideologicamente as teses sobre democracia, defendida nos Estados Unidos e Inglaterra, em medos da década de 40, corresponde ao modelo elitista / pluralista. Tal modelo sistematizado inicialmente por Joseph Schumpeter, no livro Capitalismo, socialismo e democracia, considera que a democracia é um método de escolha ou autorização de governos, ou seja, é aquele acordo institucional para chegar às decisões políticas em que os indivíduos adquirem poder de decisão por meio de uma luta competitiva pelos votos da população. O eleitor, neste sistema, é chamado para votar em que se apresenta como candidato.

Quanto ao modelo de democracia participativa, trata-se de um modelo de governo que a defende um funcionamento de uma democracia direta na base e com sistema representativo nos outros níveis de governo. As principais preocupações estão no modo de atingir esse modelo de democracia participativa assegurando aos eleitores as responsabilidades do Estado perante eles. (CORTINA, 2001, p. 94-98) Os avanços em direção à radicalização da democracia na sociedade tem ocorrido nos momentos em que a força organizativa populares consegue impor o alargamento dos direitos políticos e sociais. 
A Lei de Biossegurança sob a abordagem da ética discursiva

que moderar a ação técnica e lhe impor limites para poder excluir antecipadamente ações que desencadeiem, mesmo em um caso remoto, riscos para a humanidade e a vida no planeta. Esse poder sobre o poder deve emanar da sociedade como um todo, sendo preciso "afetar a opinião popular", os comportamentos e as leis ligadas ao campo da ciência e da técnica. E nas palavras de Oswaldo Giacoia Junior "O novo imperativo ético não se dirige (como o imperativo categórico de Kant) ao comportamento do indivíduo privado, mas ao agir coletivo, sua destinação não é, portanto, a esfera próxima das relações entre singulares, mas a do domínio da política pública.” (GIACOIA, 2000, p. 193-206).

Se, se entende como proposta minimizar ou reverter os efeitos perturbadores e irreversíveis ${ }^{14}$ do agir instrumental da biotecnologia por um controle popular, o poder discricionário da CTNBio contraria esses fundamentos éticos. Pois, nesse modelo de regulação, além de não atender ao modelo representação popular, obsta um plano de ampla participação social como forma de radicalização democrática necessária nas decisões no âmbito da biotécnica.

A participação popular nas decisões possibilita uma racionalidade comunicativa e imprimi a validade ${ }^{15}$ às normas jurídicas. Pra isso, Habermas concilia a autonomia privada com autonomia pública para a procedimentalização das respostas que devem ser dadas pelo Direito como forma de resolver as tensões no Estado Democrático de Direito. (HABERMAS, 2001).

${ }^{14}$ Hans Jonas afirma que os erros na Biotecnologia produzem efeitos irreversíveis. E isto revela a ineficácia dos mecanismos de responsabilidade civil, fundado na culpa (binômio lesão-sanção), Pois, a responsabilidade civil, nas bases do iluminismo, lida com a previsibilidade da lesão causada pela agir do indivíduo, oposto às imprevisibilidades e multiplicidades de situações das sociedades complexas diante dos avanços biotecnológicos. (KAUFMAM, 2004, p. 464).

${ }^{15}$ Para Habermas, a tensão interna entre faticidade e validade do Direito Moderno se manifesta em três níveis: na norma jurídica, no sistema de direitos e no estado democrático de direito. No nível da norma jurídica, os destinatários do direito podem obedecê-la por temor da coerção prevista na lei, proveniente de sua vigência social (faticidade) ou pela convicção que procede do reconhecimento de sua legitimidade (validade), porque o direito moderno permite que os agentes, orientados pela racionalidade comunicativa do mundo da vida, sigam as normas jurídicas pelo reconhecimento de sua legitimidade, enquanto os agentes, regidos pela racionalidade estratégica dos sistemas, calculam os custos e benefícios de obedecê-la como um fato social, no qual os custos são representados pelas sanções previstas em lei, na forma de multa ou pena de reclusão, enquanto os benefícios emanam dos lucros e vantagens 
Os direitos fundamentais da livre iniciativa e de liberdade da pesquisa científica na esfera da autonomia privada coexistem e se conciliam com a autonomia pública que representa a liberdade no âmbito de participação política das decisões. As resoluções das leis, que culminam no conteúdo jurídico da atividade biotecnológica devem ser validadas pela vontade geral, ou seja, um ordenamento jurídico motivado pelo consenso do ambiente social nos fundamentos de uma democracia deliberativa.

A autonomia privada e a autonomia pública pressupõem-se mutuamente. A conexão interna entre democracia e Estado de direito consiste em que, por um lado, os cidadãos apenas podem fazer um uso adequado de sua autonomia pública se graças a uma autonomia privada assegurada são suficientemente independentes; e por outro lado, só podem obter um equilibrado exercício de sua autonomia pública. Por isso os direitos fundamentais e os direitos políticos são indivisíveis. (HABERMAS, 2002, p. 293).

O Conselho Nacional de Biossegurança pode significar a criação de espaço público para o exercício da autonomia pública no âmbito da biotecnologia. $\mathrm{O}$ exercício da autonomia pública, com a aplicação do Princípio do Discurso e o Princípio da Universalidade, está no bojo da ética discursiva para orientar as condutas na esfera da autonomia privada.

Embora a Lei de Biossegurança tenha disposto sobre a formação do Conselho Nacional de Biossegurança $(\mathrm{CNBS})^{16}$, não há uma regulamentação para este último. Para isso, deve haver um novo tratamento legal daquele disposto na Lei de Biossegurança quanto à elaboração dos conteúdos jurídicos para a atividade biotecnológica.

de violá-la. A tensão interna entre faticidade e validade se manifesta também no sistema de direitos, por meio do qual Habermas mostra como se distinguem os direitos fundamentais individuais, políticos e sociais. O sistema de direitos somente pode ser fundamentado através da auto-legislação democrática empreendida pelos próprios cidadãos, pois, dadas as condições pós-metafísicas da Modernidade, os cidadãos não são mais capazes de aceitar a fundamentação das normas jurídicas com base no direito natural teológico, que emana da vontade de Deus, ou a partir do direito natural racional, proveniente da razão natural. Contudo, o processo democrático também tem que permitir aos autores das leis a liberdade subjetiva de escolher os motivos para aprová-las orientados estrategicamente, assim como a possibilidade de alcançar racionalmente um consenso sobre a legitimidade da lei, comprometendo-se, em última instância, com a solidariedade engendrada pela ação comunicativa no mundo da vida, porque os direitos políticos de participação e comunicação são direitos subjetivos como quaisquer outros direitos. (DURÃO, 2006, p. 108).

${ }^{16}$ Quando no século passado se manifestou o contraste entre liberais e democratas, a corrente democrata levou a melhor obtendo gradual, mas inexoravelmente a eliminação 
A Lei de Biossegurança sob a abordagem da ética discursiva

Esse novo tratamento legal deve inserir a participação do CNBS no âmbito de competência de regulamentação da atividade biotecnológica. Assim, deslocando a competência regulatória atribuída à CTNBio pela atual legislação, a principal regulamentação da atividade biotecnológica poderá ser realizada por deliberações desse conselho.

A CTNBio, pelo seu caráter técnico, poderá servir de órgão de apóio ao conselho. Na medida em que se desenvolvem os mecanismos legais de participação na gestão democráticas, reconhecê-se dois requisitos básicos para o cidadão agir paritariamente junto ao poder público: ativismo político e compreensão técnica. O primeiro diz respeito à capacidade de formular ações de finalidade pública. Já o segundo significa entender as ações que envolvem o agente público. Por isso, a necessidade de haver um trabalho educacional no conselho que pode ser desenvolvido pela CTNBio dentro das deliberações do CNBS. Tendo em vista o grau elevado de compreensão técnica nos debates e possibilidade de ampla participação de sujeitos no debate que não dominam a informação debatida, a CTNBio pode ser fundamental para a democracia participativa no papel educador pelo seu domínio do conhecimento sobre a biotécnica.

O caráter regulador deste Conselho importa para configurar uma política deliberativa de Estado Democrático de Direito e consolidar os direitos políticos, bem os direitos fundamentais no âmbito da biotecnologia. Com isso, há, estrategicamente, com fim próprio de conter os abusos da atividade biotecnológica, a procedimentalização pelo Direito ${ }^{17}$ de um agir comunicativo com os fundamentos da Ética Discursiva Habermasiana. Assim, a elaboração de conteúdos

das discriminações políticas a concessão do sufrágio universal. Hoje, a reação democrática consiste em exigir a extensão de participação nas tomadas de decisões coletivas para lugares diversos daqueles em que se tomam as decisões políticas. Consiste em procurar conquistar novos espaços para a participação popular e, portanto, em provar a passagem da fase democrática de equilíbrio para a fase da democracia de participação. (LIBERATI; CYRINO, 2003, p. 86-7). Por exigência da participação entre representação de governo e da sociedade civil nesse novo organismo, surgiu no campo do ordenamento jurídico, um novo perfil, um novo canal institucional, os Conselhos de Direitos. Esses canais de participação direta do povo asseguram uma verdadeira co-gestão, um exercício partilhado do poder político entre governantes e sociedade civil. A origem formal dos conselhos pode ser reconhecida na Constituição de 1988 no Artigo 204, inciso II.

${ }^{17}$ Em tempos pós-metafísicos e secularizados, a força coercitividade do Direito o constitui como o instrumento que melhor garante a integração social detentor de um poder unificador equivalente à religião. (ARROYO, 2000, p. 84). 
Valkíria Aparecida Lopes Ferraro; Simone Vinhas de Oliveira

jurídico da biotecnologia poderá pressupor um exercício da autonomia privada conciliada autonomia pública, ou seja, a intersubjetividade e comunicação no Biodireito.

\section{CONSIDERAÇÕES FINAIS}

$\mathrm{O}$ agir instrumental da atividade biotecnológica provoca um desequilíbrio estrutural existente nas relações sociais. A autonomia pública, sob a abordagem da ética discursiva, pode servir como importante elemento de estabilização relações sociais e, assim, como limites para os abusos da atividade biotecnológica.

Para tanto, é preciso refletir sobre os modelos de elaboração de norma que contrariam os parâmetros democráticos das decisões políticas como ocorre com a Tecnocracia da CTNBio.

Numa Democracia representativa, os critérios normativos para a atividade biotecnológica devem ser elaborados pelo poder legislativo. Porque sendo o conteúdo de relevância social da Lei de Biossegurança, a matéria é de competência legislativa do Congresso Nacional - órgão de representação popular e não um órgão tecnocrata do Poder Executivo. O retorno da regulamentação para o legislativo seria simétrico ao patrão ético-jurídico do atual modelo democrático.

Mas, a proposta de radicalização democrática, como premissa para conter os abusos da atividade biotecnológica, conduz ao padrão ético de participação política dos indivíduos. Isto aponta a necessidade de criação de espaços públicos o que converge para os fundamentos da ética discursiva habermasiana.

Ambos os modelos democrático (representação política e participação direita política) se opõe à idéia de órgão tecnocratas do poder executivo decidindo, exclusivamente, sobre temas que afetam os interesses de toda humanidade.

A formação de um Conselho Nacional de Biossegurança (CNBS) pela Lei de Biossegurança aponta um caminho para da ética discursiva porque cria procedimentos para haver uma racionalidade comunicativa.

Resta a regulamentação deste Conselho para instituir um espaço público de participação nas decisões política sobre biotecnologia. A partir da intersubjetividade e da comunicação, os quais são elementos da ética discursiva habermasiana, é possível objetivar o dever ser da atividade biotecnológica num modelo de democracia deliberativa.

\section{REFERÊNCIAS}

ARROYO, Juan Carlos Velasco. La Teoria Discursiva del Derecho: sistema jurídico e democracia em Habermas. Madrid: Centro de Estudios Políticos y Constitucionales, 2000. 
A Lei de Biossegurança sob a abordagem da ética discursiva

BOUFLEUER, José Pedro. Pedagogia da ação comunicativa: uma leitura de Habermas. Ijuí: Unijuí, 2001.

CORTINA, Adelia. Ética aplicada y democracia radical. Madrid: Tecnos, 2001.

DURÃO, Aylton Barbiere. A tensão entre faticidade e validade no direito segundo Habermas.Ethic@, Florianópolis, v. 5, n. 1, p. 103-120, jun. 2006.

DUTRA, Delamar José Volpato. Razão e Consenso em Habermas: a teoria discursiva da verdade, moral, do direito e da biotecnologia. Florianópolis: UFSC, 2005.

GIACOIA, Oswaldo Júnior. Hans Jonas: O princípio responsabilidade. In: OLIVEIRA, Manfredo (Org.). Correntes fundamentais da ética contemporânea. Petrópolis: Vozes, 2000.

FREITAG, Barbara. A Questão da Moralidade: da razão prática de Kant a ética Discursiva de Habermas. Tempo Social: Revista de Sociologia, São Paulo, v. 1, n. 2, p. 7-44, 2 sem. 1989.

HABERMAS, Jürgen. Ciência y Técnica como ideologia. Trad. Manuel Jiménez Redondo, Madrid: Tecnos, 1986.

. O Discurso Filosófico da Modernidade. Trad: Luiz Sérgio Repa, Rodnei Nascimento. São Paulo: Martins Fontes, 2000.

. Direito e Democracia: entre a faticidade e validade. Trad. Flávio Beno Siebeneichle, Rio de Janeiro: Tempo Brasileiro 2001. v. 1.

. A inclusão do outro: estudos de teoria política. Trad. George Sperber, Paulo Astor Soethe. São Paulo: Loyola, 2002.

KANT, Imanuel. Fundamentação da metafísica dos costumes: Trad. Paulo Quintela. São Paulo: Abril Cultural, 1980. (Os Pensadores).

KAUFMAM, Arthur. Filosofia do Direito. Trad. Antonio Manuel Hespanha. Lisboa: Fundação Calouste Gulbenkian, 2004.

LBERATI, Wilson Donizeti; CYRINO, Públio Caio Bessa. Conselhos e fundos no Estatuto da Criança e do Adolescente. São Paulo: Malheiros, 2003.

MCCARTHY, Thomas. La Teoría crítica de Jürgen Habermas. Madrid: Tecnos, 1998. 